\title{
Do Financial Performance And Firm Value Can Improve Corporate Responsibility Disclosure?
}

\author{
Dini Wahjoe Hapsari, Willy Sri Yuliandhari, M. Fadel Variza \\ Fakultas Ekonomi dan Bisnis, Universitas Telkom, Bandung \\ Email: dinihapsari@telkomuniversity.ac.id
}

\begin{abstract}
The aims of this research are to find out how the effect of financial performance is proxied by ROA and ROE on the firm value which is proxied by Tobin's Q with CSR that is proxied by cost allocation as moderating the plantation sub-sector listed on the Indonesia Stock Exchange for the period of 2013-2016. This research will seek the causes of whether CSR data allocation is able to strengthen or weaken the influence of financial performance on firm value. The sampling technique used was purposive sampling, and eight companies were selected as samples of plantations with a four-year research period to obtain 32 sample units. The analytical method used is descriptive statistical testing, panel data regression analysis and moderated regression analysis (MRA) using e-views software 9.0 versions. Based on the result of the test, the financial performance variables that are proxied by ROA and ROE partially and simultaneously have a significant positive effect on firm value. While the MRA showed that CSR weakens the relationship between financial performance and company value. Based on the result that the companies and investors need to pay attention to the composition of financial performance and disclosure of corporate social responsibility, hence the investor is able to minimize the risks that will be borne when investing their capital.
\end{abstract}

Keywords: Return on Asset, Return on Equity and Corporate Social Responsibility.

\section{BACKGROUND}

Plantation commodities are one of the mainstays for Indonesia's national income and foreign exchange, which can be seen from the contribution of the plantation subsector in 2013 to reach US $\$ 45.54$ billion or equivalent to Rp.546.42 trillion (assuming 1 US \$= Rp. 12.000,-) which includes export of plantation commodities of US \$ 35.64 billion, excise of tobacco products of US \$ 8.63 billion and export duty (ED) of CPO and cocoa beans of US $\$ 1.26$ billion. Plantation plays an important role in the development of a region; it is a hope that the plantation is able to create jobs for the population, as a source of income, as a means of doing business, and as a means to be able to change fate in a better direction.

The increased profits and decreased profits are experienced by plantation companies which can increase and even reduce investor confidence in the plantation subsector companies. In the high profits, it shows that companies can provide high returns as well. Conversely, with a low profit, the company gives a low return. Financial statements that only show cash receipts and payments in a short period are not sufficient to show the success of a company's performance. Financial statements are mentioned to have information content if the publication of these financial statements causes a market 
reaction. This market reaction is reflected in the existence of share sale and purchase transactions, which mean, it will also affect the volume of stock trading, stock prices or firm value (Fahmi, 2011). Financial ratios are used to provide an overview of the state of the company and can be used as a predictor for the company in the future (Hery, 2015). The company's financial performance is measured using financial ratios. Financial ratios connect various estimates contained in financial statements so that the financial condition and results of operations of a company can be interpreted (Angelia and Suryaningsih, 2015; Dewi, 2015; Lucyanda and GraciaPrilia Siagian, 2012).

According to (Hermawan and Maf'ulah, 2014), the value of the company is also called market value because it can provide maximum shareholder prosperity if the company's stock price increases. In this study, researchers using Tobin's Q to measure the value of the company are believed to be able to provide an overview of market valuation of the company, because Tobin's Q compares the ratio of market value of company shares to the book value of company equity. Because the greater the value of the Tobin's $Q$ ratio indicates that the company has good growth prospects and greater intangible assets. If the q-ratio is above one, this indicates that investments in assets generate profits that give a higher value than investment expenditure.

Financial ratios that are often used in analyzing company performance, especially profitability, are Return on Assets (ROA), which describes the extent to which the assets of a company can generate profits (Manurung et al., 2017). Assets owned by the company are tangible evidence of the company's ability to maintain its financial performance. The bigger or more assets, the more guaranteed the performance of the company. A high ROA ratio gives a positive sign for investors. Thus, the stock price will go up and a high stock price reflects good corporate value. Each ROA increases, the value of the company will increase or is called improving. The result is indicated that the increase in company profits will invite potential investors to buy company shares. This causes a rise in the value of the company. The research result of (Dewi and Tarnia, 2011) showed that ROA has an effect and has a positive relationship with firm value. This is not in line with (Sigit and Maf'ulah's, 2014) research, which showed that the result of the financial performance variable (measured by ROA) do not affect the firm value.

On the other hands to ROA, researchers also use Return On Equity (ROE) to measure a company's ability to generate profits from the investment of shareholders in the company. Equity owned by the company is also proof that we can see about how companies are able to generate a large profit. The higher Return on Equity (ROE) indicates the better because the company's profit is getting bigger. The result of (Yuliana et al., 2013) study showed that Return on Equity (ROE) has a positive direction on firm value, but it is different from the research conducted by (Carningsih, 2012) which stated that Return on Equity (ROE) does not affect the value of the company. (Jatiningrum's, 2013) indicated of the effect of financial performance on firm value by disclosure of corporate social responsibility (CSR) as a moderating variable of financial performance was measured by ROA and ROE, and the firm value measured by Tobin's Q, while CSR disclosure was measured using disclosure index CSR. The result of this study is ROA, and ROE have a significant effect on firm value and CSR disclosure has an effect on the relationship between ROA, ROE and firm value.

The social responsibility of the company will improve the company's reputation which can improve the overall performance of the company. This means that to see the 
value of the company does not always use financial performance. The market also responds to the cost allocation of CSR by the company, moreover, the allocation of CSR costs within the company is one of the factors that determine good corporate value. Or vice versa, if the company does not provide a good response to the cost of CSR can cause a decrease in the value of the company. It can be seen from the relatively low stock price and the low sales volume of the company's shares. The research from (Sigit and Maf'ulah's, 2014) showed that partially the interaction of Return On Asset variables with Corporate Social Responsibility cost allocation influences the value of the company. Based on this research, the Corporate Social Responsibility cost allocation can moderate the relationship of Return The social responsibility of the company will improve the company's reputation which can improve the overall performance of the company. This means that to see the value of the company does not always use financial performance. The market also responds to the cost allocation of CSR by the company, so that the allocation of CSR costs within the company is one of the factors that determine good corporate value. Or vice versa, if the company does not provide a good response to the cost of CSR can cause a decrease in the value of the company. It can be seen from the relatively low stock price and the low sales volume of the company's shares. (Sigit and Maf'ulah's, 2014) research shows that partially the interaction of Return On Asset variables with Corporate Social Responsibility cost allocation influences the value of the company. Based on this research, the Corporate Social Responsibility cost allocation can moderate the relationship of Return on Assets and Return On Equity to firm value. Corporate Social Responsibility can create good corporate relations with surrounding communities where the Return On Assets and Return On Equity to firm value. Corporate Social Responsibility can create good corporate relations with surrounding communities.

In this study, the disclosure of Corporate Social Responsibility (CSR) as a moderating variable is thought to be able to strengthen or weaken the influence of ROA and ROE on Firm Value. And corporate social responsibility or CSR is needed by companies to improve the company's reputation which causes to improve the overall performance of the company. Apart from financial performance, the market also responds to the cost allocation of CSR carried out by companies so that the allocation of CSR costs within the company is one of the factors that determine the value of a good company or vice versa. Companies that do not give a good response to CSR will decrease the value of the company. This will show a relatively low share price and low sales volume.

The research from (Yuniasih and Wirakusuma, 2013) examined the effect of financial performance on firm value by disclosure of corporate social responsibility (CSR) and Good Corporate Governance (GCG) as moderating variables. Financial performance, proxied by ROA, can moderate CSR disclosures measured using social disclosure indexes and company values proxied with Tobin's $\mathrm{Q}$. The result of this study is indicated that ROA proved to be influential and has a positive relationship to firm value, the disclosure of corporate social responsibility as a moderating variable proved to strengthen ROA relationship and company value. This is reversed by the research of (Dewi and Monalisa, 2016), which showed a research on the effect of disclosure of corporate social responsibility (CSR) on financial performance proxy for Return on Assets (ROA), Return on Equity (ROE) and proxy value of companies to Price to Book Value (PBV) empirically. Therefore, knowing of the existence of audit quality as a moderator variable is whether it will affect the relationship between CSR disclosure on ROA, ROE, and PBV. 
The result of this study is indicated that disclosure of Corporate Social Responsibility (CSR) affects ROA but does not affect ROE and PBV, and audit quality as a moderating variable cannot influence the relationship of CSR to ROA, ROE, and PBV.

Another research from (Khan et al., 2012), showed that CSR has a negative relationship with financial performance. And CSR cannot be a moderating relationship between financial performance and company value. This can also be caused by the value of ROA not reflecting the true value of financial performance. The research conducted by (Suhartati et al., 2011), stated that CSR does not affect the value of the company. This is due to the measurement of CSR disclosures measured by content analysis, not having an index above $70 \%$. Almost all manufacturing companies that are the sample have not revealed the entire information according to the checklist index which is a reference in measuring the level of disclosure of information on corporate social responsibility.

Based on the problems that have been raised, the researchers need to conduct research related to whether financial performance and firm value can increase disclosure of corporate social responsibility? The problem of this research is that the financial performance variable is proxied by return on assets and return on equity while the corporate value variable is measured using Tobin's $Q$ value, and disclosure variables of corporate social responsibility as moderating variables are measured by the allocation of costs incurred by the company in carrying out corporate social activities responsibility.

\section{THEORETICAL REVIEW}

Financial Performance. Financial performance can be calculated from the components in the company's financial statements. The information to calculate financial performance is reflected in the statement of financial statement (income position report), income statement (profit statement), and cash flow statement (cash flow statement) as well as other things that support as a reinforcement of the financial performance assessment. The company's financial performance can be proxied by Return on Assets (ROA) and Return on Equity (ROE):

\section{a. Return on Asset}

This ratio calculates the company's net income to total assets in the Financial Position Report. This ratio is used to assess how much the rate of return on assets owned.

$$
\text { Return On Assets (ROA) }=\frac{\text { Net Profit After Taxes }}{\text { Total Asets }}
$$

\section{b. Return on Equity}

This ratio calculates the company's net profit from equity/ investment of shareholders. This ratio is used; therefore, the stockholders pay attention to the shares invested for management. Or in other words, this ratio is used as a measure to assess how much the rate of return of the shares themselves is invested in the business.

$$
\text { Return On Equity (ROE) }=\frac{\text { Net Profit After Taxes }}{\text { Equity }}
$$


Firm Value. Firm value is used to assess the company as a whole. This is an important concept for investors because it is an indicator of the market to assess the company as a whole. Firm value is the value paid by prospective buyers if the company is sold. Based on this, it can be said that firm value is an important concept for investors.

Tobin's Q is one tool that can be used to measure firm value. This ratio is considered to provide the best information because it can explain various phenomena in company activities such as the occurrence of cross-sectional differences in investment decision making and diversification, the relationship between management share ownership and firm value (Sukamulja, 2004).

$$
\operatorname{Tobin}^{\prime} \mathrm{s} \mathrm{Q}=\frac{M V E+D}{B V E+D}
$$

Corporate Social Responsibility. Corporate Social Responsibility is a continuing commitment from the business world to act ethically and contribute to the economic development of the local community or the wider community. It can be concluded that the definition of CSR is a commitment from an organization or company as a business actor in the form of responsible behavior that contributes to sustainable economic improvement and considers the expectations of stakeholders in line with applicable laws and norms.

$$
\text { Cost allocation }=\frac{\text { Costs of social responsibility on }(\text { ) }}{\text { net profit (loss) at the time }(\mathrm{t}-1)}
$$

Effect of Return On Assets (ROA) on Firm Value. The Return on Assets (ROA) ratio is a tool used to see how much investment has been invested can provide a return on profits. Investments, in this case, are placed company assets (Masliza et al., 2016). The high value of ROA shows the high profitability of the company seen from total assets.

A high ROA ratio is a good sign for investors, which result in stock prices going up. High stock prices are an indication of the high value of the company. If ROA rises, it will be followed by an increase in company value, which indicates an increase in company profits. High company profits will invite prospective investors to buy company shares or it is mentioned that the company's value increases.

It is in line with the research of (Dewi and Tarnia, 2011), showed that ROA has an effect and has a positive relationship to firm value. But it is not in line with the research of (Hermawan and Maf'ulah, 2014), the result of this study is indicated that ROA does not affect on firm value.

Effect of Return on Equity (ROE) on Firm Value. According to the research of (Choi et al., 2010) investigated the relationship between CSR and financial performance of companies in Korea using a sample of 1,222 companies during 2002-2008. This study measures corporate social responsibility by both the same weighted CSR index and the weighted stakeholder index. The company's financial performance is measured by return on assets, return on equity and Tobin's Q. By using cross-sectional regression analysis; the study reported a positive and significant relationship between CSR and weighted weight index, but do not have the same CSR index. Return on Equity (ROE) is used to measure the effectiveness of a company in generating profits by utilizing the equity it owns. Return 
on Equity (ROE) is the ratio between profit after tax to total equity originating from the owner's capital deposit, non-divided profit and other reserves collected by the company. A measure of the financial performance of investors and senior managers is Return on Equity (ROE).

Return on Equity (ROE) proved to have a significant positive effect on firm value. This is indicated that companies that have a high Return on Equity (ROE) of unchanged fixed costs will increase the company's profits available to shareholders. Therefore investors tend to invest in these companies, and if the demand for shares by investors increases, the value of the company will also increase (Febriana, 2013).

Disclosure of Corporate Social Responsibility (CSR) on Firm Value. One of the company's activities that have much of public attention is reporting on economic, social and environmental activities. Reporting on corporate social responsibility is important because more and more companies carry out CSR disclosures that can enhance the company's reputation and ultimately improve company performance. The market also pays attention to the cost allocation of CSR carried out by the company, so that the cost allocation of CSR in the company is one of the factors that determine good corporate value. Or vice versa if the company does not provide a good response to the allocation of CSR data, the company's value will be bad. This is characterized by the declining stock price and the low sales volume of shares owned by the company. This is in line with the research of Hermawan and Maf'ulah (2014), showed that partially the interaction between Return On Asset and Corporate Social Responsibility cost allocation has a significant effect on firm value. This means that the Corporate Social Responsibility cost allocation variable is able to moderate the relationship of variables Return on Asset and Return on Equity with firm value. Corporate Social Responsibility can create good corporate relations with surrounding communities.

\section{METHODOLOGY}

This research is conducted to find out how the influence of financial performance is proxied by Return on Assets and Return on Equity on firm value with the moderating variable of Corporate Social Responsibility in Agriculture Sector Companies in the Plantation Sub Sector listed on the Indonesia Stock Exchange in 2013-2016. The research method used is quantitative, sample selection using purposive sampling on plantation companies with a total sample of 8 companies used in this study. The sampling method in the study is as follows: (1) All companies included in the Agriculture sector of the Plantation Sub Sector are listed on the Indonesia Stock Exchange and have published financial statements in a row from 2013 to 2016, (2) Companies in the Agriculture sector The Plantation Sub-Sector do not experience delisting during the observation period, (3) Companies in the Agriculture Sector, Agriculture Sector Sub-Sector report the company's financial statements in full during 2013-2016, (4) Have complete data relating to the research variable.

The statistical method used to test the relationship between one dependent variable and one or more independent variables is a regression (Ghozali, 2013). To test the effect of independent variables on the dependent variable is done using panel data regression analysis which aims to explain the magnitude of the effect of profitability (ROA and ROE) 
on firm value (Tobin's Q). Data analysis is used e-views, with panel data regression analysis which is a common effect model, fixed effect model, random effect model, chow test, Lagrange Effect test, and Moderate Regression Analysis and hypothesis test.

The Result of Statistical Tests. Panel data regression analysis is conducted to find out the relationship between financial performance which is proxied by ROA and ROE on firm value proxied by Tobin's Q.

\section{Significance Test of the Common Effect and Fixed Effect (Chow Test)}

Chow test is used to determine whether the model used in the study is the Common Effect Model or the Fixed Effect Model.

Table 1. The Chow Test

\begin{tabular}{|c|c|c|c|}
\hline Redundant Fixed Effects T & & & \\
\hline Equation: Untitled & & & \\
\hline Test cross-section Fixed ef & & & \\
\hline Effects Test & Statistic & d.f & Prob \\
\hline Cross-section F & 10.595537 & $(7.22)$ & 0.000 \\
\hline Cross-section Chi-Square & 47.201988 & 7 & 0.000 \\
\hline Cross-section fixed effects & & & \\
\hline Dependent Variable: NP ( & lue) & & \\
\hline Method: Panel EGLS (Cro & eights) & & \\
\hline Date: $10 / 23 / 17$ Time: 08: & & & \\
\hline Sample: 20132016 & & & \\
\hline Periods included: 4 & & & \\
\hline Cross-sections included: 8 & & & \\
\hline
\end{tabular}

Source : (Data processed by the researcher,2018)

Based on Table 1 the result of the Chow Test showed that the probability value of the Prob value (cross section F) of 0.0000 smaller than the 5\% significance rate. This showed that the probability value ( $\mathrm{p}$-value) $<0.05$, then according to the decision that $\mathrm{H} 1$ is accepted or the chosen model is a fixed effect. It can be concluded that the fixed effect model is more appropriate than the common effect. After the chow test was completed, it was followed by the Hausman test.

\section{The Hausman Test}

The Hausman test is used to determine whether the fixed effect model is better than the random effect model, with the following decision-making provisions:

Table 2. The Hausman Test

\begin{tabular}{|c|c|c|c|}
\hline \multicolumn{4}{|c|}{ Correlation Random Effects - Hausman Test } \\
\hline \multicolumn{4}{|l|}{ Equation: Untitled } \\
\hline \multicolumn{4}{|c|}{ Test cross-section Fixed effects } \\
\hline Test Summary & Chi-Sq. Statistic & Chi-Sq & Prob \\
\hline
\end{tabular}




\begin{tabular}{|l|l|l|l|}
\hline Cross-section random & 11.081844 & 2 & 0.0039 \\
\hline
\end{tabular}

Source : (Data processed by the researcher,2018)

Based on Table 2, the result of the Hausman Test, is obtained that the result of the random effect significance test, by the cross-section probability value of 0.0039 smaller than the 0.05 significance level which indicated that the probability value (p-value) $<0.05$ then corresponds to provisions for decision making that Ho is rejected and $\mathrm{H} 1$ is accepted or this study uses a fixed effect model. Hence, the right method in this study is the fixed effect method. The table below presents the result of statistical tests using the fixed effect model.

In this study, the dependent variable used is firm value and the independent variable used is financial work consisting of return on assets (ROA) and return on equity (ROE), while the moderating variable is corporate social responsibility (CSR). The sample used in this study was plantation companies listed on the Indonesia Stock Exchange in 2013-2016. The test result is shown in Table 3 as follows:

Table 3. The Fixed Effect

\begin{tabular}{|c|c|c|c|c|}
\hline \multicolumn{5}{|c|}{ Dependent Variable: NP (Company Value) } \\
\hline \multicolumn{5}{|c|}{ Method: Panel EGLS (Cross-section-weights) } \\
\hline \multicolumn{5}{|c|}{ Date: $10 / 23 / 17$ Time: 08:32 } \\
\hline \multicolumn{5}{|l|}{ Sample: 20132016} \\
\hline \multicolumn{5}{|l|}{ Periods included: 4} \\
\hline \multicolumn{5}{|c|}{ Cross-sections included: 8} \\
\hline \multicolumn{5}{|c|}{ Total Panel (balanced) observation: 32} \\
\hline Variable & Coefficient & Std. Error & t-statistic & Prob \\
\hline $\mathrm{C}$ & 0.613214 & 0.073417 & 8.352535 & 0.0000 \\
\hline ROA & 12.76176 & 2.648112 & 4.819192 & 0.0000 \\
\hline ROE & -3.609481 & 1.002363 & -3.600971 & 0.0012 \\
\hline \multicolumn{5}{|c|}{ Weight Specification } \\
\hline R-squared & 0.530222 & \multicolumn{2}{|c|}{ Mean dependent var } & 1.222763 \\
\hline Adjusted R-squared & 0.497824 & \multicolumn{2}{|c|}{ S.D. dependent var } & 0.866610 \\
\hline S.E. of regression & 0.521446 & \multicolumn{2}{|c|}{ Sum squared resid } & 7.885270 \\
\hline F-statistic & 16.36566 & \multicolumn{2}{|c|}{ Durbin-Watson stat } & 0.678289 \\
\hline Prob(F-statistic) & 0.000017 & & & \\
\hline \multicolumn{5}{|c|}{ Unweighted Statistics } \\
\hline R-squared & 0.418248 & \multicolumn{2}{|c|}{ Mean Dependent Var } & 0.879288 \\
\hline Sum squared resid & 9.581526 & \multicolumn{2}{|c|}{ Durbin-Watson stat } & 0.539274 \\
\hline
\end{tabular}

Source : (Data processed by the researcher,2018)

Based on Table 3, the regression equation can be seen from the test result of the significance of the Fixed Effect as follows:

a. The constant value is 0.061314 , which means that this value showed if the independent variable in the regression, which is a financial performance which includes return on assets and return on equity, is 0 or constant, then the company value in the plantation company will be 0.061314 . 
b. The coefficient of return on assets is 12.76176 which is positive, which means that if there is a change in the value of ROA 1 unit with the assumption that other variables are constant, the value of the company will increase by 12.76176 .

c. The coefficient of return on equity of 3.609481 is negative, which means that if there is a change in ROE 1 unit assuming other variables are constant, the value of the company will experience a deviation of 3.609481 .

\section{Hypothesis test}

Simultaneous Test (F-Test). The F test is used to find out whether the independent variables (ROA and ROE) simultaneously or together have a significant effect on the dependent variable (Firm Value). Provisions for decision making in this test are if the significance value is $>0.05$, then Ho is rejected, which means that the independent variable has an effect on the dependent variable.

The test results in Table 3 found that the Fixed Effect Significance in this study, showed the $F$ test statistic value of 0.000017 which means that the value is smaller than the value of the significance level of 0.05 so that Ho is rejected. From these values, it can be concluded that financial performance which is proxied by ROA and ROE simultaneously has a significant effect on firm value.

Determination Coefficient Test $\left(\mathbf{R}^{2}\right)$. The determinant coefficient is used to explain how much the proportion of the dependent variable is explained by the independent variable. The coefficient value that determines one means independent almost gives all the information needed to predict the independent variable.

Based on the result of the test for the fixed effect model presented in Table 3, the Fixed Effect Significance, the Adjusted R-Squared value was obtained at 0.497824 or 49.724\%. This is indicated that the independent variable namely financial performance which includes return on assets (ROA) and return on equity (ROE) is able to explain the dependent variable, which is firm value 0.497824 or $49.724 \%$ while the remaining $50.276 \%$ is explained by other variables outside the research.

Partial Test (t-Test). According to (Ghozali, 2013), the t-test statistic is used to show how far one explanatory variable or individually independent in explaining the dependent variable. Provisions for t-test decision making are if the probability value ( $p$-value) $<0.05$ is rejecting Ho, means that the independent variable has a significant influence on the dependent variable partially. But if the probability value ( $p$-value)> 0.05 then accept Ho, means that the independent variable does not have a significant effect on the dependent variable partially. Table 4 below is partially the result of a statistical test.

Table 4. The t-Test

\begin{tabular}{|l|}
\hline Dependent Variable: NP (Firm Value) \\
\hline Method: Panel EGLS (Cross-section-weights) \\
\hline Date: $10 / 23 / 17$ Time: $08: 32$ \\
\hline Sample: 20132016 \\
\hline Periods included: 4 \\
\hline Cross-sections included: 8 \\
\hline Total Panel (balanced) observation: 32 \\
\hline
\end{tabular}


Hapsari, Yuliandhari, Variza: Do Financial Performance and Firm Value Can Improve...

\begin{tabular}{|l|l|c|c|c|}
\hline \multicolumn{5}{|l|}{ Test cross-section Fixed effects } \\
\hline \multicolumn{4}{|l|}{ Linear estimation after one-step weighting matrix } \\
\hline \multicolumn{1}{|c|}{ Variable } & Coefficient & Std. Error & t-statistic & Prob \\
\hline C & 0.613214 & 0.073417 & 8.352535 & 0.0000 \\
\hline ROA & 12.76176 & 2.648112 & 4.819192 & 0.0000 \\
\hline ROE & -3.609481 & 1.002363 & -3.600971 & 0.0012 \\
\hline
\end{tabular}

Source : (Data processed by the researcher,2018)

Based on Table 4 which is shown the result of the test for the fixed effect method, therefore, the result of the partial test (t-test) can be described in the form of a panel data regression equation as follows:

1. Variable return on assets (ROA) has a probability value of 0.0000 which means that the probability of return on assets (ROA) is smaller than the significance level of 0.05 , so it can be concluded that Hol is rejected, which means that financial performance is calculated based on proxy ROA partially affects the value of the company on plantation companies listed on the Indonesian Stock Exchange for the period 2013-2016.

2. The return on equity (ROE) variable has a probability value of 0.0012 which means that the probability of return on equity (ROE) is smaller than the 0.05 significance level, so it can be concluded that Ho2 is rejected, which means that financial performance is calculated based on ROE partially affect the company value of plantation companies listed on the Indonesian Stock exchange for the period 20132016.

Test of Interaction for Moderate Regression Analysis (MRA). The MRA analysis was conducted to determine the effect of CSR in moderating the effect of financial performance which is proxied by ROA and ROE on firm value proxied by Tobin's Q. Interpretation of the result can be seen in Table 5 below:

Table 5. The Result of the Moderate Regression Analysis Interaction

\begin{tabular}{|c|c|c|c|c|}
\hline \multicolumn{5}{|c|}{ Dependent Variable: NP } \\
\hline \multicolumn{5}{|c|}{ Method: Panel Least Squares } \\
\hline \multicolumn{5}{|c|}{ Date: 04/16/18 Time: 11:39 } \\
\hline \multicolumn{5}{|l|}{ Sample: 20132016} \\
\hline \multicolumn{5}{|l|}{ Periods included: 4} \\
\hline \multicolumn{5}{|c|}{ Cross-sections included: 8} \\
\hline \multicolumn{5}{|c|}{ Total panel (balanced) observations: 32} \\
\hline Variable & Coefficient & Std. Error & t-Statistic & Prob. \\
\hline $\mathrm{C}$ & 0.668604 & 0.091735 & 7.288424 & 0.0000 \\
\hline ROA & 7.872777 & 2.557765 & 3.077991 & 0.0062 \\
\hline ROE & -2.129142 & 0.894976 & -2.378994 & 0.0280 \\
\hline CSR & -0.144175 & 2.763092 & -0.052179 & 0.9589 \\
\hline
\end{tabular}


Hapsari, Yuliandhari, Variza: Do Financial Performance and Firm Value Can Improve...

\begin{tabular}{|l|l|l|l|l|}
\hline ROA*CSR & -41.74211 & 120.3754 & -0.346766 & 0.7326 \\
\hline ROE*CSR & 30.10999 & 53.86060 & 0.559036 & 0.5827 \\
\hline
\end{tabular}

Source : (Data processed by the researcher,2018)

The MRA regression equation means that the intercept coefficient of 0,668604 is positive which means that if the CSR variable, Interaction 1 (ROA * CSR) and Interaction $2(\mathrm{ROE} * \mathrm{CSR})$ are constant then the firm value will increase by 0.668604 while the CSR coefficient $(Z)$ of 0.144175 marked negative, which means that if there is a change in the value of CSR by 1 unit assuming other variables are constant, the value of the company will decrease by 0.144175 . For the interaction coefficient 1 (ROA $*$ CSR) of 41.74211 , it is negative, which means that if there is a change in the interaction value of 1 by 1 unit assuming that the other variables are constant, the value of the company will be adjusted by 41.74211 . And the interaction coefficient 2 (ROE * CSR) of 30.10999 is positive which means that if there is a change in the interaction value of 1 unit assuming that other variables are constant then the value of the company will increase by 30.10999 .

\section{ANALYSIS AND DISCUSSION}

Descriptive Analysis ROA, ROE, CSR, and Firm Value. The result of the test is found in descriptive statistics for the Return on Assets (ROA), Return On Equity (ROE), Corporate Social Responsibility and Firm Value variables are shown in the following table:

Table 6. Descriptive statistics

\begin{tabular}{|l|c|c|c|c|c|}
\hline \multicolumn{1}{|c|}{ Variabel } & Mean & Maximum & Minimum & Std Deviasi & Observation \\
\hline Company Value & 0,9146 & 3,3367 & 0,0388 & 0,7289 & 32 \\
\hline ROA & 0,0277 & 0,1830 & $-0,4363$ & 0,1106 & 32 \\
\hline ROE & 0,0625 & 0,2727 & $-1,3522$ & 0,3136 & 32 \\
\hline CSR & 0,0055 & 0,1316 & $-0,1370$ & 0,0453 & 32 \\
\hline
\end{tabular}

Source : (Data processed by the researcher,2018)

Based on table 6, it can be seen that the ROA variable during the 2013-2016 period has a mean value of 0.0277 with 18 samples that have ROA above average and there are 14 samples that have ROA below the average. This showed that the plantation sub-sector companies have high asset returns, so they are able to disclose CSR costs in their annual reports.

ROE variable has a mean value of 0.0625 with 20 samples having ROE above average and 12 samples having ROE below average. This showed that plantation subsector companies have the ability to use their resources through equity owned.

And CSR variables have a mean of 0.0055 with 4 samples above the average and 28 samples below the average. The number of 4 samples above the average value of CSR indicated that there are few plantation sub-sector companies that disclose or calculate CSR costs in annual reports.

Firm value is an investor's perception of the level of success of the company reflected in the stock price or in other words the value of the company is equal to the stock price. Firm value is measured using Tobin's Q. 


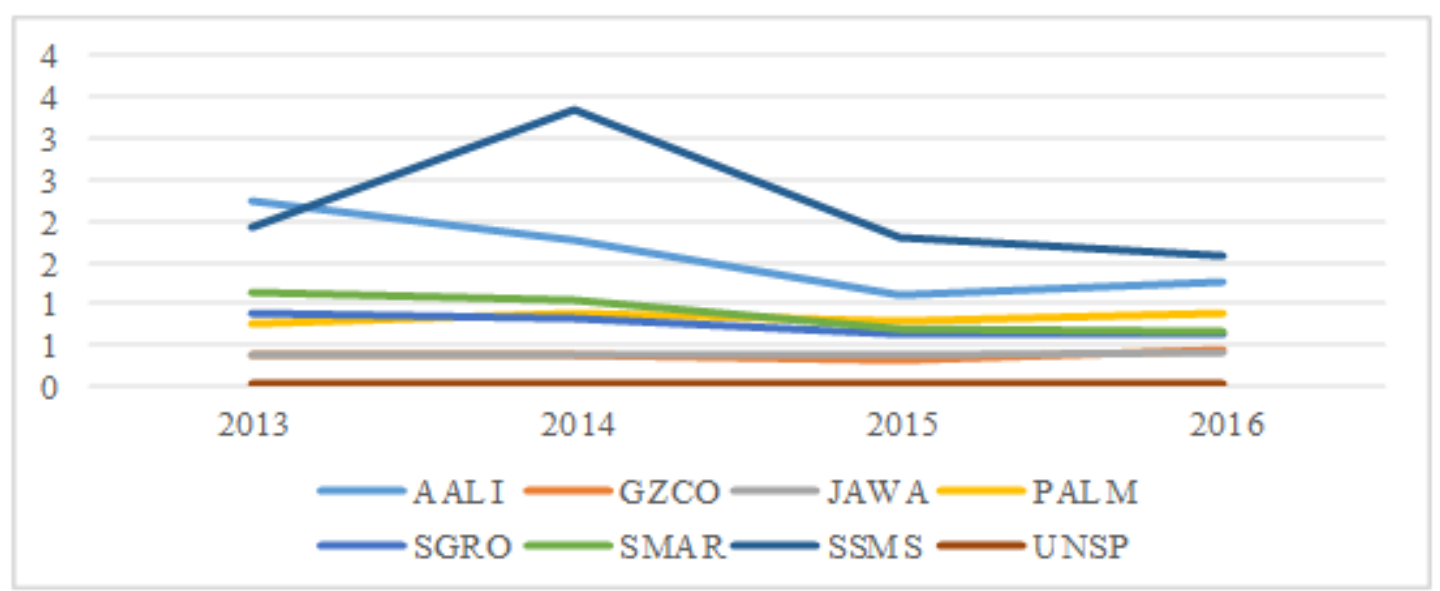

Figure 1. Value of Plantation Companies for Period 2013-2016 Period

Based on Figure 1 Plantation Company Value for period 2013-2016, it is seen that Tobin's Q value which relatively rose in 2013 to 2014 and experienced a decline in 2015 then increased again in 2016. In this movement, it was seen that the fluctuated value of plantation companies in the period 2013-2016.

The Effect of Return on Assets to Firm Value. Return on Asset is a measure to assess how much the rate of return of assets owned by a company. This ratio which is a calculation of the company's net profit based on total assets is used because in absolute terms a company that earns profits that increase is not necessarily relatively increased before being compared with the assets used to generate the profit.

The result of The partial test (t-test), can be seen in Table 5, the Interaction Moderate Regression Analysis which presents that ROA has a probability of 0.0000 smaller than the significance level of 0.05 and indicated that the decision taken is accepting Ha1 and rejecting Ho1, thus, it was concluded that financial performance variables that were proxied by ROA had an effect on firm value. The ROA coefficient value in Table 4 showed that there is a unidirectional relationship between ROA and firm value, if the ROA value increases, it will increase the value of the company and vice versa. This is in accordance with the hypothesis made by the author if the ROA value is higher than the value of the company will be higher. That is, plantation companies that are experiencing financial conditions or bad asset returns, the company's value are also worse.

The result of this study is in line with the research of (Dewi and Tarnia, 2011), that ROA has an effect on firm value. Investors before investing can calculate performance using ROA to predict the value of the company. Investors always hope to get a high return on their investment and want to get the maximum profit.

The Effect of Return on Assets to Firm Value with Corporate Social Responsibility as Moderating Variable. The result of the test in Table 5 showed that the Interaction of Moderate Regression Analysis, financial performance variables that are proxied by Return On Assets (ROA) which are moderated by Corporate Social Responsibility in which are proxied by CSR cost allocation that has a significance value of 0.7326>0.05 so Ho1 is accepted. Hal showed that Return On Asset after being moderated by CSR has no effect and has a positive relationship to firm value. The cost of CSR allocation does not 
strengthen the effect of Return On Assets on the value of the company. This means that the lower Return on Asset after being moderated by CSR will cause the company value to decline.

In regulation No. 40 of 2007, it is explained that companies that carry out their business activities related to natural resources must carry out social and environmental responsibilities. CSR disclosure is used as a medium for companies to provide information about the social aspects of the company. By giving information disclosure, it will give consideration to investors before investing and can provide trust to investors. The market response to the allocation of CSR costs makes the allocation of CSR costs one of the factors that determine good corporate value. If there is no market response to the allocation of CSR costs, the company is considered to have a bad firm value.

The Effect of Return on Equity to Firm Value. The result of the test in Table 5 that the Interaction of Moderate Regression Analysis, financial performance variables are proxied by Return On Equity with a probability value of $0.0280<0.05$. So that it can be concluded that financial performance variables that are proxied by ROE have an influence on firm value. The regression coefficient on the ROE variable is positive which is shown that there is a unidirectional relationship between ROE and firm value, if the ROE value increases, it will increase the value of the company and vice versa. This is in accordance with the hypothesis made by the author, where if the ROE value is higher than the value of the company will be higher. Hence, plantation companies that are experiencing financial conditions or a poor return on equity, the firm value are also getting worse. The result of this study is in line with the result of the research of (Abar and Aprilia, 2012) which stated that Return On Equity (ROE) has an influence on firm value.

The Effect of Return on Equity to Firm with Corporate Social Responsibility as Moderating Variable. Based on the result of the research is shown in Table 5 that Interaction of Moderate Regression Analysis, financial performance variables that are proxied by Return On Equity (ROE) moderated by Corporate Social Responsibility in which are proxied by CSR cost allocation that have a significance value of $0.5827>0.05$ so Hol is accepted, this proved that Return On Equity after being moderated by CSR does not significantly influence the positive direction of firm value, which means that the cost of CSR allocation does not strengthen the effect of Return On Equity on firm value. This means that the lower Return on Equity after being moderated by CSR will cause the company value to decline. This means that the lower Return on Equity after being moderated by CSR will cause the firm value to decline. And the interaction coefficient 2 (ROE * CSR) of 30.10999 is positive which means that if there is a change in the interaction value of 1 unit assuming that other variables are constant then the value of the company will increase by 30.10999 . And it can be concluded by returning the decision that Hol is accepted but CSR cannot strengthen because it is positive and significant towards the relationship between ROE and firm value. 


\section{CONCLUSION}

Based on the result and discussion that has been done, the conclusions from the study is showed that the financial performance variable is proxied as return on assets with firm value stating that if the return on assets value is higher then the value of the company will increase.

In the financial performance variable proxied by return on assets with moderation in the disclosure of corporate social responsibility to company value, the lower the return value on company assets, the company will experience a decrease in the value of the company causing disclosure of corporate social responsibility. Firm value stated that if there is an increase in return on equity, the value of the company will increase so that it is able to contribute. Return on Equity variable on firm value with disclosure moderation, corporate social responsibility states that the value of Return on Equity in high companies does not always increase the value of the company, this can be caused by the moderating variable disclosure of corporate social responsibility that is not able to increase firm value. Whether the company discloses corporate social responsibility does not necessarily make investors interested in investing.

Suggestion. In making the investment, investment decisions can use ROA, ROE, and CSR to get capital gains or profits derived from investments such as stock prices. The higher the capital gain, the higher the value of the company. Based on the result of the study showed that ROA and ROE proved to be influential and had a positive relationship to firm value, while the allocation of CSR costs does not influence or weaken the relationship between financial performance and company value, therefore, it became a consideration for investors. Investors should not only look based on the allocation of CSR costs but also look at the types of CSR activities carried out by the company. For companies that have the main goal to maximize company value which can be reflected in the company's stock price, it is important to pay attention to the factors that will affect the company's stock price itself. As well as companies can increase the value of ROA and ROE because in this study proven ROA and ROE have an influence on company value and CSR that is proxied by cost allocation as a variable of moderation that weakens or decreases the value of the company. Moreover, having improved financial, companies should also continue to maintain the continuity of social activities in order to further enhance the company's image.

\section{REFERENCE}

Angelia, D., and Suryaningsih, R. (2015). The Effect of Environmental Performance And Corporate Social Responsibility Disclosure Towards Financial Performance (Case Study to Manufacture, Infrastructure, And Service Companies That Listed At Indonesia Stock Exchange). Procedia - Social and Behavioral Sciences, 211(November), 348-355. https://doi.org/10.1016/j.sbspro.2015.11.045

Carningsih. (2012). Pengaruh Good Corporate Governance Terhadap Hubungan Antara Kinerja Keuangan Dengan Nilai Perusahaan (Studi Kasus Pada Perusahaan Property Dan Real Estate YangTerdaftar Di Bursa Efek Indonesia). E-Journal Ekonomi Universitas Gunadharma. 
Choi, J.-S., Kwak, Y.-M., and Choe, C. (2010). Corporate social responsibility and corporate financial performance: Evidence from Korea. Australian Journal of Management, 35(3), 291-311. https://doi.org/10.1177/0312896210384681.

Dewi, D. M. (2015). The Role of CSRD on Company's Financial Performance and Earnings Response Coefficient (ERC). Procedia - Social and Behavioral Sciences, 211(September), 541-549. https://doi.org/10.1016/j.sbspro.2015.11.072.

Dewi, R.R. dan Tarnia, T. (2011). Pengaruh Kinerja Keuangan terhadap. Nilai Perusahaan dengan Good Corporate Governance sebagai. Variabel Moderasi. Jurnal Informasi, Perpajakan, Akuntansi dan. Keuangan Publik.Vol.6, No.2, Juli 2011.

Dewi, Kartika dan Monalisa (2016). Effect Of Corporate Social Responsibility Disclosure On Financial Performance With Audit Quality As A Moderating Variable. Binus Business Review, Vol 7, No. 2, pp. 149-155.

Fahmi, Irham. (2011) Analisis Laporan Keuangan. Bandung: Alfabeta.

Ghozali, Imam. 2013. Ekonometrika "Teori, Konsep, Dan Aplikasi Dengan Spss 17". Semarang: Universitas Diponegoro.

Hery. (2015). Analisis Laporan Keuangan. (Edisi 1). Yogyakarta: Center For Academic Publishing Services.

Hermawan, Sigit dan Afiyah Nurul Maf'ulah. (2014). Pengaruh Kinerja Keuangan Terhadap Nilai Perusahaan dengan Pengungkapan Corporate Social Responsibility Sebagai Variabel Pemoderasi. Jurnal Dinamika Akuntansi, Universitas Negeri Semarang, Semarang.

Jatiningrum, C. (2013). Pengaruh Kinerja Keuangan Terhadap Nilai Perusahaan Dengan Pengungkapan Corporate Social Responsibility (CSR) Sebagai Variabel Pemoderasi. Jurnal Ilmiah Gema Ekonomi, 3(2), 345-354.

Khan, A., Muttakin, M. B., and Siddiqui, J. (2012). Corporate Governance and Corporate Social Responsibility Disclosures: Evidence from an Emerging Economy. Journal of Business Ethics, 114(2), 207-223. https://doi.org/10.2139/ssrn.2050630.

Lucyanda, J., and GraciaPrilia Siagian, Lady. (2012). The Influence of Company Characteristics Toward Corporate Social Responsibility Disclosure. The 2012 International Conference on Business and Management (pp. 601-619). Phuket, Thailand.

Manurung, Daniel T H, R. Wedi Rusmawan Kusumah, Dini W Hapsari dan Fitria Husnatarina (2017). Effect Corporate Governance, Financial Performance and Environmental Performance on Corporate Social Responsibility Disclosure. International Journal of Arts and Commerce, Vol. 6 No. 5.

Marnelly, T. Rommy (2012). Corporate Social Responsibility (CSR): Tinjauan Teori dan Praktek di Indonesia. Jurnal Aplikasi Bisnis. Vo. 2, No. 2. Pp. 49-59.

Putu, Ni Nyoman G Martini. (2014). Factors Affecting Firms Value of Indonesia Public Manufacturing Firms. International Journal of Business and Management Invention. SSN (Online): 2319 - 8028, ISSN (Print): 2319 - 801X. Brawijaya University. Malang..

Qiu. Y., Shaukat, A. and Tharyan, R. (2014). Environmental and Social Disclosure Link With Corporate Financial Performance, The British Accounting Review, pp. 1-5.

Ramadhani, S. L., dan Prajitno, B. H. (2012). Pengaruh Corporate Social Responsibility terhadap Nilai Perusahaan dengan Prosentase Kepemilikan Manajemen sebagai 
Variabel Moderating pada Perusahaan Manufaktur yang terdaftar di BEI. Journal Akuntansi \& Auditing Volume 8, 8(2), 1-12.

Yuniasih., Ni Wayan dan Wirakusuma, Made Gede (2013). Pengaruh Kinerja Keuangan Terhadap Nilai Perusahaan Dengan Pengungkapan Corporate Social Responsibility dan Good Corporate Governance sebagai Variabel Pemoderasi. Jurnal AUDI, Vol. 4, No., 1. https://doi.org/10.24843/JIAB.2009.v4.i01.

Yuliana, Akbar D.A, dan Aprillia R, (2013). "Pengaruh Skruktur Modal dan Return On Equity (ROE) terhadap Nilai Perusahaan” Jurnal Akuntansi, STIE MDP. 